\title{
HOME OFFICE OPPORTUNITIES IN SME'S IN BACK OFFICE
}

\section{[Př́ležitosti plynoucí z uskutečňování práce $\mathrm{z}$ domu pro potřeby malých a středních podniků]}

\author{
Michał Barański ${ }^{1}$, Gábor Mélypataki ${ }^{2}$, Zoltán Musinszki ${ }^{3}$, Katalin Lipták ${ }^{4}$ \\ ${ }^{1}$ University of Silesia in Katowice, Faculty of Law and Administration, Bankowa 11b, 40-007 Katowice, Poland \\ Email: michal.baranski@us.edu.pl \\ ${ }^{2}$ University of Miskolc, Faculty of Law, 3515 Miskolc, Hungary \\ Email:melypataki.gabor@uni-miskolc.hu \\ ${ }^{3}$ University of Miskolc, Faculty of Economics, 3515 Miskolc, Hungary \\ Email: musinszki.zoltan@uni-miskolc.hu \\ ${ }^{4}$ University of Miskolc, Faculty of Economics, 3515 Miskolc, Hungary \\ Email:liptak.katalin@uni-miskolc.hu
}

\begin{abstract}
Recent times have shown that we need to address issues such as electronic communication related to home office and telecommuting. In many places, the physical workplace has been transformed into a back office-type organizational unit. Exchange of information between an employee working in a home office or teleworking and the back office. In our study below, we examined how the exchange of information between the individual units can be implemented in Hungary and Poland. In this study, we examine the legal and economic framework. We examined the relationship between digitization and SMEs through job advertisements and a questionnaire survey. The focus of our study was on accounting and decision support tasks. Our research question: What are the expectations of SMEs nowadays for accounting and decision support tasks and jobs? What are the labour law implications and consequences of these expectations?
\end{abstract}

Keywords: COVID-19, digitalization, labour law, SME's.

JEL classification: E24, J54, K31

Received: 10.2.2021; Reviewed: 25.2.2021; 6.3.2021; Accepted: 19.5.2021

\section{Introduction}

Automation, digitalization and globalization have an effect on nowadays global labour market. The process of change has become increasingly apparent also in Hungary and in Poland. Both the employed and the employee have to adapt themselves to the rapidly changing circumstances. The aim of the paper is to examine the requirements of novel processes and their labour market effects impose upon the potential labour force and labour law.

Earlier we analysed the situation of SME's in Hungary and Poland (Mélypataki et al. 2020) and we observed the working time conditions (Musinszki et al. 2020). Now we decided to analyse a very important topic: the choice of these types of activity for analysis is particularly important due to the recently adopted provisions on the digitalization of employee files in some national laws. Simultaneously, the changes introduced regarding the digitalization of personal files may, in certain aspects, raise questions of interpretation. In Poland, on 1.1.2019, the entire Act of 10.1.2018 on amending certain acts due to the shortening of the period of storage of employee files and their digitalization came into force. The different form of keeping personal files by employers may cause difficulties, for example, in the event of a takeover of employees. In such a situation, an employer keeping personal files of its employees in paper form may not be 
prepared to take over records maintained in electronic form by an employer whose employees are being taken over.

For the issues under consideration here, the problem of regulations in force in both countries regarding teleworking and remote working is also relevant, especially during the COVID-19 pandemic. In the case of teleworking, in addition to the digitialization of personal files, the verification of the data on the device used by the employee also raises questions. The protection of personal data and personal space is also a particularly important aspect, which is also emphasized in the SME sector.

\section{National trends in the digitalization of employee files}

In Poland, on 1.1.2019, the entire Act of 10.1.2018 on amending certain acts due to the shortening of the period of storage of employee files and their digitalisation came into force (Journal of Laws of 2018, item 357). At the stage of the draft amendment, the Polish legislator indicated that the new regulations would result in a reduction of costs by employers due to longterm paper storage of employees' files, which is estimated at approximately PLN 130,000.00 per year (Draft of 6.7.2016 of the assumptions of the draft act on amending certain acts due to the shortening of the period of storage of employee files and their digitalization).

Following the new wording of Article 94, point 9a of the Polish Labour Code (Journal of Laws of 2020, item 1320), the employer is obliged, in particular, to "keep and store in paper or electronic format documentation concerning any matters related to the employment relationship and the personal files of employees (employee documentation)".

In contrast to the Polish practice, the Hungarian rules do not consider it so important that they regulate the digitization of labour registers in a separate section. This is not to say that it is not possible to keep these records in digitized form, in fact a large proportion of multinational companies use them. Act I of 2012 on the Hungarian Labour Code nor does it lay down a general obligation to keep records, but mentions the obligation separately for each legal institution. The Hungarian LC mentions that the employer's obligation under $\S 51$ (1) is that the employer is obliged to employ the employee in accordance with the employment contract and the rules of the employment relationship. The main question is not whether it is necessary to keep records and in what form, but what content and compliance with GDPR rules. Where we find special rules is the public service sector, where there is a separate government decree on personnel records. In the case of SMEs, the demand was rather lower due to the small number of employees. However, working from home also transforms the practices of these businesses.

According to the new Article $94^{11}$ of the Polish Labour Code, from 1.1.2019, "employee documentation kept and stored in electronic format shall be equivalent to employee documentation kept and stored in paper format". To eliminate interpretation doubts which may arise in connection with the application of the provisions on changing the form of employee documentation, it has become justified to express the norm directly based on which the paper and electronic forms of employee documentation produce the same legal effects, in particular in terms of the provisions of the labour law and social insurance (Justification of the government's draft act on amending certain acts due to the shortening of the period of storage of employee files and their digitalization, parliamentary print No 1995). The analysed regulation is also aimed at ensuring compliance of the adopted solutions with the requirements of Regulation (EU) No 910/2014 of the European Parliament and of the Council of 23 July 2014 on electronic identification and trust services for electronic transactions in the internal market and repealing Directive 1999/93/EC (eIDAS) (OJ L 257, 28.8.2014, p. 73-114), 
according to which an electronic document shall not be denied legal effect and admissibility as evidence in legal proceedings solely on the grounds that it is in electronic form.

In Hungarian regulations, Act V of 2013 on the Civil Code. $\S 6: 7$ itself defines the role of legal declarations in a neutral manner in order to determine the written quality of legal declarations made in a manner other than in the form of a statement, when it provides that a legal declaration shall be deemed to be and the date on which the declaration is made is identified in an appropriate form. For this, it is necessary to mention the additional rules of labour law. Section 22 (2) of the Hungarian Labour Code emphasizes that the legal declaration itself is the same if the above-mentioned content elements are retained. Employers use electronic registration systems within this general legal framework. Neutral rules for electronic documents focus primarily on data content. (Bankó 2015)

As of 1.1.2019, Articles $94^{4}-94^{6}$ were also added to the Polish Labour Code, regulating in detail the rules for the storage of employee documentation, for example, in a situation where it may constitute or constitutes evidence in proceedings, and the employer is a party to those proceedings or has become aware of the filing of a claim or the initiation of proceedings. In turn, new Articles $94^{7}-94^{10}$ regulate the procedure for destroying, changing the form and collecting the previous form of employee documentation. For the indicated changes to be system, they also explicitly include provisions of the social insurance law (Article 3 of the stated amendment). Transitional provisions are also included in detail in the Act of 10.1.2018. Moreover, as of 1.1.2019, the Regulation of the Minister of Family, Labour and Social Policy of 10.12.2018 on employee documentation is in force in Poland (Journal of Laws of 2018, item 2369). This Regulation specifies in particular the scope, manner, and conditions of keeping, storing, and changing the form of employee documentation, taking into account requirements for documentation in electronic format concerning the organisation of its processing and transferring between ICT systems.

The rules for the management of electronic and other records are set out in Hungary in Act CXII of 2011 on Information Self-Determination are located in. The legislation has recently been amended by the European Union's GDPR Regulation. It has also changed the way employees 'personal data is handled. However, the regulation did not step out of the previous round, when its focus was on data protection. This is also important in that it should be mentioned here not only the records that the employer is obliged to keep and keep himself, but also towards the tax authority and other supervisory authorities. Regardless of their size, companies are obliged to use the so-called "Company Gateway", which is an internet public platform on which even registration obligations can be fulfilled. It is a common practice that SMEs are also increasingly forced to use electronic files.

The different form of keeping personal files by employers may cause difficulties, for example, in the event of a takeover of employees. In such a situation, an employer keeping personal files of its employees in paper form may not be prepared to take over records maintained in electronic form by an employer whose employees are being taken over (Letter of the Minister of Family, Labour and Social Policy, 19.7.2016, DP.I.02200.117.2016.MS). According to the Polish Ministry of the Family, Labour and Social Policy, the introduced regulations should also assume that "an employee may not bear any costs related to the employer's choice of electronic storage of personal data maintained and stored in electronic form". At the same time, it should be pointed out that the intention of the drafters was "that the employee should not bear any costs related to the digitalization, as it is the employer who chooses this form, who will be obliged to provide the employee with the necessary tools for electronic record keeping and 
documentation" (Arrangements of 8.8.2016 - Summary of comments on the draft assumptions of the assumptions of the draft act on amending certain acts due to the shortening of the period of storage of employee files and their digitalization). However, it should not be overlooked that the transfer of electronically maintained documentation will most often be accompanied by a change in the ICT system, which means that documentation must be transferred in the manner set out in the Regulation mentioned above (Chapter 4 - Transfer of employee documentation between ICT systems).

\section{The problem of regulations regarding teleworking and remote working}

For the issues under consideration here, the problem of regulations in force in both countries (Hungary and Poland) regarding teleworking and remote working is also relevant, especially during the COVID-19 pandemic.

We need to start from the concept of telework. Teleworking is a regular activity carried out in a place separate from the employer's premises, which is performed by a computer device and its results are transmitted electronically (Vallasek \& Mélypataki 2020). This form of work was suitable for millions of people around the world, including Hungary and Poland, despite the introduction of social distance and \#stayathome.

As of March 8, 2020, the Polish Act of 2 March 2020 on special solutions related to preventing, counteracting and combating COVID-19, other infectious diseases and emergencies caused by them is in force (Journal of Laws of 2020, item 374 as amended, hereinafter referred to as "COVID-19 Act"). According to Article 3(1) of the Act mentioned above, in the period of validity of an epidemic emergency or a state of epidemics, declared due to COVID-19, and in 3 months after their cancellation, to counteract COVID-19, an employer may order an employee to perform, for a specified period, work specified in the employment contract, outside the place of its regular performance (remote work). The scope of cases justifying the issuance of the order in question is vast (the need for prophylaxis itself, as a form of preventing infections, is sufficient) (Baran 2020, Barański 2020).

Another form of providing work within the employment relationship framework, which is telework, should be distinguished from remote work within the Act's meaning analysed here. Pursuant to Article $67^{5} \S 1$ of the Polish Labour Code ,work may be performed away from the premises of an employer, on a regular basis, by means of information and communications technologies (ICTs) within the meaning of the provisions on rendering services by electronic means (telework)".

In Hungary, the emergency situation was declared almost simultaneously with the Polish regulations by Government Decree 40/2020 (III.11.). Government Decree 47/2020 (III.18.) Changed the labour law rules. In this regulation, the legislator emphasized that the home office and telework order could be ordered unilaterally by the employer. Of particular interest to this provision is that the Hungarian Labour Code does not really contain rules for the home office. Teleworking is a named atypical form of work. (Mélypataki, Máté \& Rácz 2020) The latter has a practice based on legislation and theory, and the home office has only practice. As we will see later, this regulation was unfortunate because it confused these two legal institutions. The home office is a special way of organizing working time within the classic labour law relation, teleworking and atypical forms of work based on a contract.

In Poland, the laconic regulation of Article 3 of the COVID-19 Act and the numerous similarities between remote work and telework in principle make it impossible to distinguish 
between these two legal constructions unambiguously. The literature emphasizes that "the only criteria for differentiation are that at present the performance of remote work is possible only to counteract COVID-19, the results of remote work do not have to be sent each time using electronic communication or similar means of individual communication at a distance, and the remote work itself is by definition of a temporary character (fixed period)". At the same time, it should be borne in mind that within 3 months from the date of commencement of telework during employment, either party may make a binding request to cease telework and to restore the previous conditions of work. After the expiry of this deadline, the reinstatement of the previous working conditions by the employer may be effected by way of a change notice (Article $678 \S 1$ and 3 of the Labour Code).

Similarly to the above, Hungarian regulation faces a similar problem for home office and teleworking. However, the legal dogmatic basis of seemingly identical forms differs rigidly. A home office is a form that can be ordered temporarily, in which working from home is the essence, which of course can be done with an ICT tool, but it is not necessary. However, in the case of telework, what is certain is that it can be ordered not only on an ad hoc basis, and the work and the transmission of the results of the work. Teleworking and the home office are both activities typical of office workers, so many times there is no difference in appearance. In any case, the home office could only be ordered for a maximum of 44 working days in the context of employment other than an employment contract.

In the longer term, the Polish legislator must intervene and regulate unambiguously at the Labour Code level the institution of remote work (not only as a construction aimed at counteracting COVID-19) (Leśniak 2020). Until then, it should be considered reasonable (per analogiam) to apply the regulation of telework to remote work (to the extent not regulated by the anti-covid law), at least when remote work is performed using means of direct communication at a distance (Barański 2020). K. Baran and D. Książek allow for "in case of a construction gap, the applicability using the mechanism of the adequacy of the Code norms concerning telework to remote work based on the argumentation a simili in the version of analogia legis, subsidiarily even with the application of the ab exemplo mechanism. Indeed, it should be borne in mind that Article 3(1) of the COVID-19 Act does not eliminate the application of the Labour Code, but only changes some of the facts of the employment relationship, especially as regards the form and place of providing work during the pandemic period" (Baran 2020).

The introduction of remote work to the Labour Code should be connected with the need to modify the regulation concerning not only telework, but also work in a cottage industry (Barański 2020). In the case's specific facts, it is difficult to determine whether remote work is performed under conditions of subordination and in-person (especially when performing manufacturing parts) (Barański 2020).

The changed labour market environment would require new regulation, especially as the role of teleworking has changed. In Hungarian law, its definition and the rules on employer control are dominant. The legislature promised a renewed regulation for the fall of 2020 that would become almost nothing. A 487/2020. (XI.11.) Formulated a general flexibility in a government decree. According to the decree, the parties are free to deviate from the rules on telework contracts set out in $\S 196$ of the Labour Code. In our opinion, similar to the Polish rules, it makes the position of the employee as a vulnerable party more difficult. Due to the mixing of the individual forms and the high degree of flexibility, the warranty elements are eliminated. In addition to the above, occupational safety regulations have been eliminated. 


\section{The characteristics of SME's}

Digitalisation, which sweeps through all areas of life, does not avoid accounting either. The 6D model can be linked to Peter Diamandis and Steven Kotler, which aims to show how digital technology is evolving and what change this evolution will bring to the environment around us (Diamandis - Kotler 2015). The first stage is digitalisation itself, when the information becomes digital, that is, they will be suitable for computer processing. In the field of the accounting profession, this means recording invoices into an accounting programme. In the next stage (2D) the nature of the digital process is described, which is characterised initially by growing slowly, unnoticeable, and then, after a point, its growth soars rapidly, and the usual things are completely destroyed and usually eliminated. After the destruction comes the stage (3D) where we can enjoy the positive effects of change and these digital technologies become completely free for everyone and everywhere. As a result of digitalisation, a structural change is taking place in the focal points of the accounting service. Currently, data recording dominates. Be it accounting data or tax data. This data recording-based service model is evolving today, with an increasing emphasis on consulting-focused service. (Mélypataki et al. 2020)

This part of our study presents this process through the example of a Hungarian accounting firm (see Orosz 2018). How the accounting firm makes use of the opportunities provided by digitalisation.

The accounting firm was established in 2011 to provide accounting services to small and medium-sized enterprises, as well as sole proprietors, foundations and associations. The firm is currently associated with a total of 86 companies. In terms of legal form, the office predominantly coordinates the accounting services of limited liability companies and sole proprietors. In terms of the size of the companies, micro and small enterprises are in the majority. They provide their services to businesses in almost all areas of economic life. Examples are education, commerce, real estate, transportation, warehousing, construction, restaurants or other services. The firm mainly performs accounting and payroll tasks, but also provides general legal advice to its clients. The day-to-day operations of the company are managed by the managing director and with the participation of four employees in a family atmosphere. Employees maintain close contact with their customers and are constantly available to them to resolve all issues and problems affecting their business. (This relationship, as we shall see, does not require a personal presence. The solutions used by the firm allow smooth working even during COVID-19.)

The main activity of the office is therefore data providing to the authorities within the time limits in the manner and with the data content required by the relevant laws. Such declaration can be a VAT declaration, a company car tax declaration, a corporate tax declaration, a business tax declaration, a tax declaration on wages paid and an annual report which can be found in the basic fee invoiced to companies. As a non-regular service, it undertakes the preparation of other declarations of the company, or the writing of tenders, as well as provides assistance during the transformation of the company form. It is also present at the start-up of the business when drafting the memorandum or the articles of association, and provides advice on tax conditions for both start-ups and existing companies. The manager also has a law degree, so he occasionally gives general legal advice. The owner of the office does not provide financial advice or information on domestic economic changes, but is glad to monitor and warn businesses about changes in the regulations that affect them.

The firm opted for a cloud-based service or otherwise known as 'cloud-computing' to process its invoices. The benefits are clear, as they are not tied to using it in a fixed place, they can have 
access to the materials they need to work with almost anywhere, anytime. This solution allows for flexible scheduling for both office staff and clients. By using a cloud-based service, the office is not only free from the cost of hardware and software purchases, but also from a significant portion of the cost of maintaining the building of the office. After all, this solution supports not only flexible working hours, but also home office. This flexibility has helped maintain and increase the competitiveness of the accounting firm in previous years. However, in the situation that emerged in March 2020, this is no longer just a means of competitiveness, but also a means of survival.

We know that an accountant spends most of their time processing data, that is processing incoming invoices. Suppliers' invoices are processed by the Billcity accounting software. Here, it is possible for the accountant to scan the invoices of suppliers he has received from his clients using a scanner and then upload them to the interface. It is not necessary to print the invoices in pdf format, they can be imported into the system immediately. The Billcity program recognises the number of invoice, partner data and amount on the invoices with $85 \%$ security, thus simplifying and also speeding up the accounting tasks. Billcity also stores scanned invoices in a cloud, making them easy to find, even years back if needed. No need to search the archives for folders, no more problems with lost invoices because everything can be found in its original form. The program handles all types of invoice, scanning long blocks in the same way as multipage copies. Checking the data is also easy, as the monitor shows the invoice and the data to be recorded next to it.

The IMA accounting program provides cloud-based operation, which allows you to post and perform various queries from the posted data anywhere and anytime. The program requires an active Internet connection and a Microsoft Windows operating system. The system can thus be used without geographical or temporal constraints. Parallel work is also solved, not only can the accounting firm use it, the given company can also gain insight into the workflows, but it can even invoice from the system. Daily, weekly, monthly and annual backups are also stored, this and the operating environment provide the highest level of data security available today. The system has three main functions: finance and accounting function, stocking and warehousing area, and workflow and worksheet management.

The firm also uses a program called Viki, the assistant accountant, which helps accountants in a way that they do not have to manually send all kinds of tax and contribution notifications to their clients. Users can give the items to be paid for in advance, when they are determined, to Viki, which sends the notification emails to the customers completely automatically, at the right time, instead of the accountants. In addition, it connects the various interfaces of the Hungarian Tax Authority (NAV) to the accounting program, monitors the status of tax declarations, monitors daily activities, and is able to present up-to-date results to clients, but this function of the program is not currently used by the accounting firm.

\section{Methodology and results}

So the office is already taking advantage of the opportunities provided by information technology. The new programs introduced provide an opportunity to actively involve customers in the use of the programs in the future, thus providing them with instant data on the financial condition of their business. The primary goal of the solutions presented so far has been to minimise the work involved in data management in the past. By now, the objective function has been expanded with flexibility, both in terms of working hours, place of work and customer relations. 
But where is the office's advisory function? In order to get to know the expectations of the customers, we conducted a questionnaire survey.

The purpose of the questionnaire survey was to see if there was a need for clients to develop a management reporting system to be developed by the accounting firm. The query was made using Google Forms. The questionnaire consisted of the following sections:

- data on ownership and management,

- questions related to the operation of the business,

- questions related to management information needs.

The questionnaire was sent by the head of the office from the official e-mail address of the office to the e-mail addresses of the clients. Out of 86 customers, the questionnaire was completed by 57 companies. $64.92 \%$ of the respondents are micro, $33.33 \%$ are small and $1.75 \%$ are medium-sized enterprises.

Figure 1: The importance of priority reports $(n=57)$

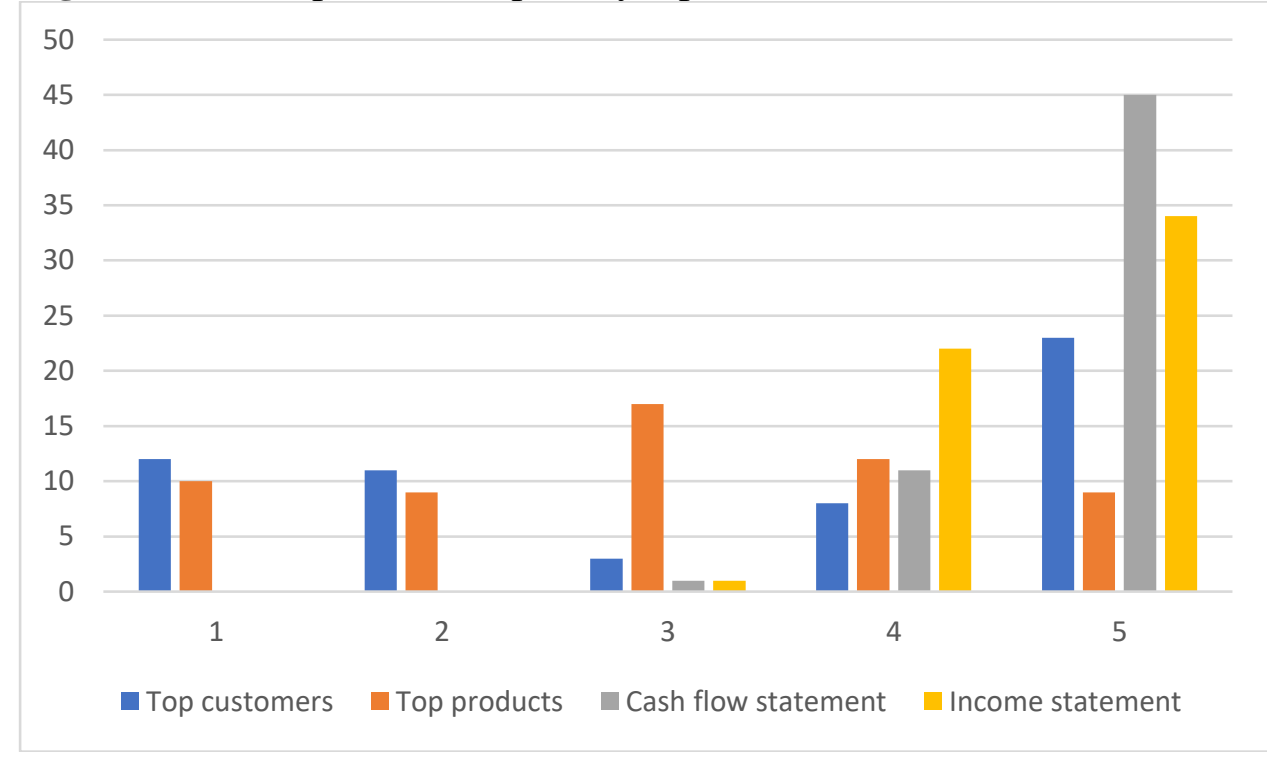

Source: Own editing

According to the forms of company: $47.36 \%$ are limited liability company, $21.07 \%$ sole proprietorship, $19.29 \%$ non-profit organisation and $12.28 \%$ limited partnership. In the questionnaire, we examined how important the reports in the questionnaire were considered by the clients of the office. (See Figure 1.) A five-point Likert scale was used for the measurement (1: not at all, 5: largely). Concerning reports on turnover, both limited liability companies and limited partnerships each gave the highest value. The evolution of costs was considered very important by all respondents. In most cases, monthly reports would be preferred. We were also curious to see if companies wanted to see change in cash flow in addition to revenue and expenses. Accounting distinguishes between revenues and cash inflows and between costs and expenses. For all forms of company, respondents considered cash flow reporting to be more important than income statement. The need to examine the most successful product or service varies widely. Customers consider this type of report to be moderately important. In the case of the detection of the customers with the highest turnover, the same pat-tern can be observed as in the former case. Most of the points were given by limited liability companies. $77 \%$ of the LLCs would like to see a summary made on their top customers. Examining the claims, it can be seen that limited liability companies demand this type of report the most, 5 points were given by a total of 18 clients. 


\section{Conclusion}

The legal background to teleworking raises unregulated issues so far, so there is already a need in the economy for the SME side to take advantage of cloud-based technology. Apparently, there is a need for this (survey), it helps SMEs, but the legal dilemmas need to be resolved by human resources. The Hungarian and Polish rules developed similarly when developing the rules related to teleworking. They didn't really become transparent and usable. The legislature confused the concept of a home office and teleworking. Practice dealt with these concepts separately before the pandemic, and we believe that this should be treated separately now as well. The many similarities I oppose differ on both dogmatic and practical grounds. As a result of the rules, definitions and life situations in both countries have become confused. The legislator was not particularly interested in this. In addition, the new rules that have been introduced do not serve legal certainty and, above all, do not protect workers. So many certain workers were dismissed or forced into the home office without effective protection.

These legal anomalies are detrimental to SMEs working in the business field in several ways. It is a problem for the business and the employee, and it is a problem for the business and the customer. In the age of digitalisation, SMEs no longer see their accountants as just data loggers and tax professionals. They also count on them to support decision-making and inform SME leaders. Thus, the range of services required from accountants is expanding.

In the survey, respondents were also asked about the services of the accounting firm. All respondents would welcome a report from the office on pre-calculated, expected annual result and sales revenue. This would help them judge whether they are on the right track. (Comparison of plan-fact data.) Businesses are open to self-control (87.71\% of respondents would like to expand their knowledge of controlling as well), while $100 \%$ of clients felt that it was necessary to expand the role of accountants towards consulting. We asked how important it would be for the enterprises to be provided with information relevant to his decisions by their accountants. $86 \%$ of customers would consider these pieces of information and reports especially important.

\section{References}

[1] BANKÓ, Z., 2015. Elektronikus dokumentumok a munkaviszonyban- a munkajogi jognyilatozatokkal szemben támasztott követelmények a digitális világban. Downloaded: 17.12.2015 http://www.kjmalapitvany.hu/sites/default/files/szakertoipalyazat/tanulm\%C3\%A1ny_banko_zoltan.pdf

[2] BARAN, K., 2020. Tarcza antykryzysowa. Szczególne regulacje w prawie pracy, prawie urzędniczym i prawie ubezpieczeń społecznych. Komentarz, Warszawa: Wolters Kluwer.

[3] BARAŃSKI, M., 2020. Praca zdalna w czasach COVID-19. In: M. Jankowska, M. Pawełczyk (eds.). Moda i design w świecie COVID-19. Seria Prawa Designu, Mody $i$ Reklamy. Vol. VII. Katowice: Instytut Prawa Gospodarczego sp. z o.o.

[4] DIAMANDIS, P. and D. KOTLER, 2015. Bold: How to Go Big, Create Wealth and Impact the World. New York: Simon \& Schuster Publisher.

[5] LEŚNIAK, G. J., 2020. Pracodawcy apelują o wprowadzenie pracy zdalnej na stałe. Downloaded: 3.2.2021 https://www.prawo.pl/kadry/czy-praca-zdalna-zostaniewprowadzona-na-stale-do-polskiego,501803.html

[6] MÉLYPATAKI, G. et al., 2020. SMEs in Hungary and in Poland: A Comparative Analysis of Legal and Labour Relations In: LARSEN, C. et al. (eds) The Importance of SMEs as Innovators of Sustainable Inclusive Employment: New Evidence from Regional and Local Labour Markets, München: Rainer Hampp Verlag, pp. 79-102. 
[7] MÉLYPATAKI, G., D. A. MÁTÉ and Z. RÁCZ, 2020. Forms of Working from Home in Hungary. 2nd Virtual International Conference Path to a Knowledge Society-Managing Risks and Innovation. Nis: Research and Development Center "IRC ALFATEC.

[8] MUSINSZKI, Z. et al., 2020. Workaholism and a New Generation - Labour Market Survey among Hungarian and Romanian Youth. Amifiteatru Economic, vol. 22, no. 14, pp. $1227-1242$.

[9] OROSZ, É., 2018. Kontrolling tevékenység egy könyvelöirodában (master thesis). Miskolc: University of Miskolc.

[10] VALLASEK, M. and G. MÉLYPATAKI, 2020. Rules on Home Office Work and Telework in Romania and in Hungary. Central European Journal of Comparative Law, vol. 1, no. 2, pp. 177-191. doi:10.47078/2020.2.177-191

\section{Legislative sources:}

Arrangements of 8.8.2016 - Summary of comments on the draft assumptions of the assumptions of the draft act on amending certain acts due to the shortening of the period of storage of employee files and their digitalization. Downloaded: 3.2.2021 https://legislacja.rcl.gov.pl/projekt/12291757

Draft of 6.7.2016 of the assumptions of the draft act on amending certain acts due to the shortening of the period of storage of employee files and their digitalization. Downloaded: 3.2.2021 https://legislacja.rcl.gov.pl/projekt/12291757

Justification of the government's draft act on amending certain acts due to the shortening of the period of storage of employee files and their digitalization, parliamentary print No 1995. Downloaded: 3.2.2021 https://sejm.gov.pl

Letter of the Minister of Family, Labour and Social Policy, 19.7.2016, DP.I.02200.117.2016.MS. Downloaded: 